\title{
SNRNP25 wt Allele
}

National Cancer Institute

\section{Source}

National Cancer Institute. SNRNP25 wt Allele. NCI Thesaurus. Code C134680.

Human SNRNP25 wild-type allele is located in the vicinity of 16p13.3 and is approximately $5 \mathrm{~kb}$ in length. This allele, which encodes U11/U12 small nuclear ribonucleoprotein $25 \mathrm{kDa}$ protein, is involved in mRNA processing. 